\title{
Blood loss and Procedure Time in Major Salivary Glands Benign Tumors Resection Using Harmonic Scalpel.
}

Carrillo Rivera Jorge Arnulfo ${ }^{1 *}$, Quiñones Ravelo René ${ }^{2}$, Martínez Pérez José Ricardo ${ }^{2}$, Gallardo Huerta Víctor Omar ${ }^{3}$, González López Annel Ivonne ${ }^{4}$, Radilla Flores Mariana del Carmen ${ }^{4}$, Ramírez Landeros Joshua ${ }^{5}$, Gamboa Ramírez Fernando ${ }^{5}$, Torrejón Hernández Carlos Adrián ${ }^{5}$, Hidalgo Delgado Jesús Nicolás ${ }^{5}$

'Oral and Maxillofacial surgeon at General Hospital "Dr. Darío Fernández Fierro" ISSSTE. México.

${ }^{2}$ Dentist General Practice

${ }^{3}$ Third year resident in Oral and Maxillofacial Surgery.

${ }^{4}$ Second year resident in General Surgery.

${ }^{5}$ First year resident in General Surgery.

*Corresponding author: Jorge Carrillo Rivera. Dpto. de Cirugía Maxilofacial Hosp. Gral. Dr. Darío Fernández. ISSSTE. Consultorio particular.

Received Date: March 04, 2020; Accepted Date: March 10, 2020; Published Date: March 16, 2020.

Citation: Jorge Arnulfo C R, Quiñones R René, José Ricardo M P, Víctor Omar G H, Annel Ivonne G L. (2020) Choledochogastric Fistula after Recurrent Acute Cholangitis Post-Cholecystectomy. Journal of Surgical Case Reports and Images, 3(3): Doi:10.31579/2690-1897/025

Copyright: () 2020 Jorge Carrillo Rivera, This is an open-access article distributed under the terms of the Creative Commons Attribution License, which permits unrestricted use, distribution, and reproduction in any medium, provided the original author and source are credited.

\section{Abstract}

Ultrasonic vibration is mainly used in minimally invasive surgery since it uses longitudinal mechanical waves with the ability to propagate in a solid and liquid medium, conducted to the tissues through an active tip, a large amount of vibrational energy is produced at the point of contact getting the section, coagulation and dissection of tissue.

Objective. To evaluate the operating time and blood loss in major salivary glands benign tumors resection using harmonic scalpel during the period from August 2018 to March 2019 at the Dr. Darío Fernández General Hospital.

Material and methods. Twelve patients with benign salivary gland tumors of both sexes between 39 and 76 years of age were included for the study, time and intraoperative bleeding were quantified and analyzed with measures of central tendency.

Results: The most frequently performed surgery was submaxilectomy (50\%), followed by superficial parotidectomy (33.3\%) and submaxilectomy plus lymph node resection (16.6\%). The intraoperative time lasted from 20 to 65 minutes with an average 44.16 minutes, bleeding in milliliters ranged from 25 to 60 milliliters with a mean of $42.9 \mathrm{ml}$.

Conclusions: The use of ultrasonic vibration significantly reduces operating time and blood loss due to coagulation and cutting simultaneously with less heat production.

Keywords: ultrasonic vibration; minimally invasive surgery; head and neck; benign tumors; whartin tumor; lipoma; oncocitoma.

\section{Introduction}

The hemostasis systems applied in surgery are based on the production of endothermic heat as a result of an interaction between energy and tissue [1]. Progressively more sophisticated electrocoagulation systems such as the ultrasonic scalpel based on the protein's destructiveness have been developed of the cell membrane as a result of ultrasonic vibration, generating significantly low temperatures $\left(50\right.$ to $\left.100^{\circ} \mathrm{C}\right)$ compared to the electro cautery $\left(100\right.$ to $\left.150^{\circ} \mathrm{C}\right) .3 \mathrm{It}$ is an apparatus that uses mechanical energy to cauterize the vessels and dissect the tissues; It consists of three components, a generator that provides electricity, this is transformed into energy through a system of piezoelectric crystals that vibrate in an amplitude between 50 to $330 \mu \mathrm{m}$, at a constant frequency between 23 to $55.5 \mathrm{kHz}$, the expansion and contraction of These crystals are sent by means of a handpiece that attaches to the active tip either to a scalpel or to scissors [2,3]. Figure 1.

Ultrasonic coagulation is similar to that of the electrocautery, however, the mechanism by which the protein is denatured is due to the transfer of mechanical energy, breaking the tertiary hydrogen bonds, the protein tissue is transformed into a viscous collagen that cauterizes the small and medium diameter vessels $[3,4]$.
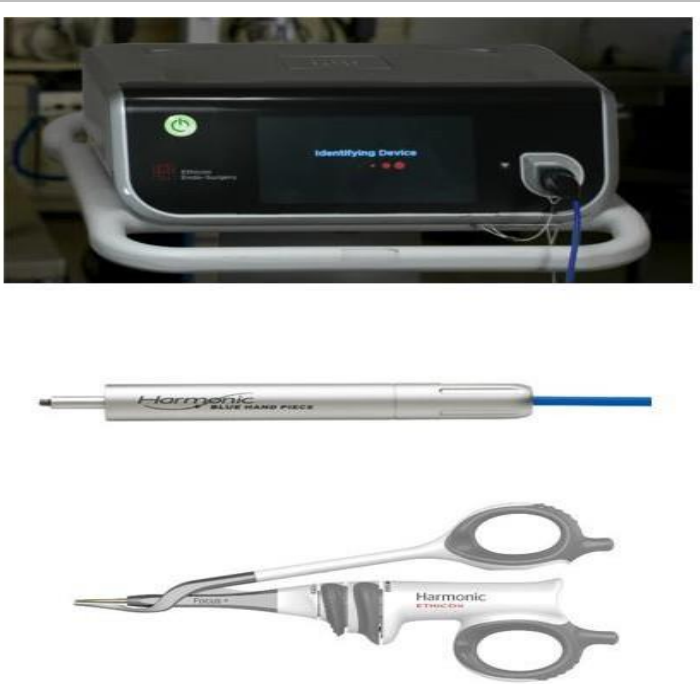

Figure 1. Generator, Handpiece and Scissors Harmonic, FocusMR (Jhonson \& Jhonson). 
There are two mechanisms by which tissues are dissected, one is by means of cavitation fragmentation and the second by mechanical cutting at temperatures below $63{ }^{\circ} \mathrm{C}$; Vibration defragments proteins with the breakdown of hydrogen bonds (tertiary hydrogen bonds). It can be used simultaneously for cutting and coagulation, since it transfers the neuromuscular current and produces a minimal lateral thermal effect ( 1 to $3 \mathrm{~mm}$ ). After cutting and coagulation, it causes minimal intraoperative bleeding, which allows the surgeon a better view of the operative field, so the surgery lasts less time than with other techniques and causes minimal tissue damage, which leads to scarring of faster wounds, lower postoperative morbidity and decreased postoperative pain [2, 4 and 5]. The surgical time is known as the time in minutes used in the surgical procedure obtained from the anesthesiology report sheet, from the beginning of the surgical incision in the skin to the closure of it. The transsurgical bleeding defined as the volume of bleeding in milliliters reported on the anesthesiology sheet resulting from the count in the aspiration manifold and the estimation by gauze used. Over the years, various methods have been reported for the quantification of intraoperative bleeding, some of these methods are considered impractical and obsolete. According to current literature, visual estimation is the most widely used method despite its low accuracy [6].

The quantification of bleeding by the weight of textiles is considered the most practical and accurate method to determine the amount of blood not captured in the containers, which is obtained by subtracting the dry weight of absorbent textiles and the weight of textiles with blood material, using the conversion of $1 \mathrm{~g}=1 \mathrm{ml}[6]$.

\section{Clinical case 1}

This is a 54-year-old male patient, with a 3-year hemifacial asymmetry of evolution in the right buccal region of slow growth, asymptomatic, soft consistency and well-defined edges, not hyperemic or hyper thermic.
With a history of uncontrolled systemic arterial hypertension, osteoarthritis and gonartrosis of the left lower limb, on treatment based on pregabalin and etoricoxib 1 tablet every 24 hours. In the simple tomography, a hypo dense area was observed in the circumscribed right oral space of 6 x 5 centimeters. Figure 2

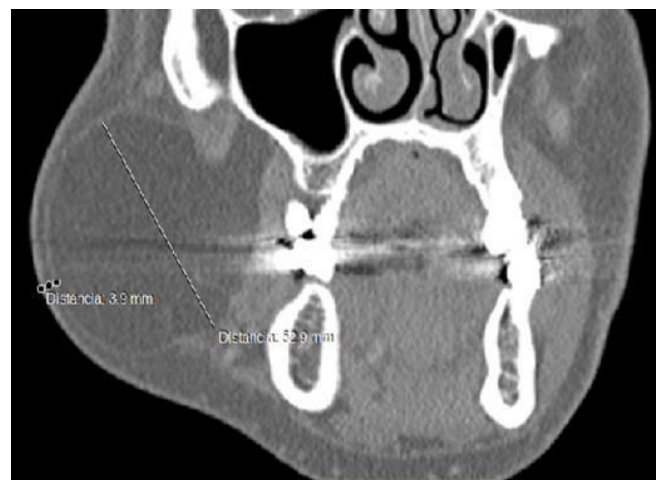

Figure 2: Coronal section tomography in which hypo dense lesion is well circumscribed in the right oral space.

Intraoral fine needle aspiration biopsy (BAAF) of the lesion was performed and the lamellae were sent to the pathology laboratory where mature adipose tissue with lymphocyte infiltrate and surrounded by fibrous stroma with a diagnostic interpretation compatible with lipoma was reported. Figures $3 \mathrm{~A}$ and B.
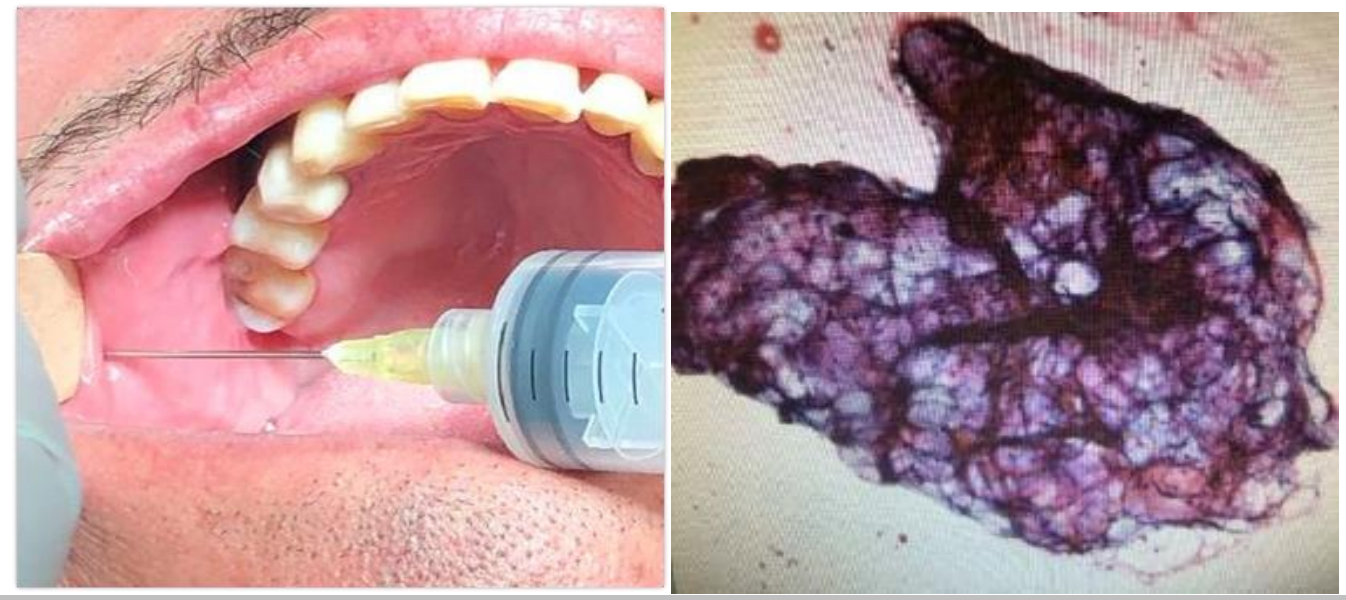

Figure 3. A: Fine Needle Aspiration Biopsy. B. Extended cell composed of adipocytes with extensive cytoplasm. (Pap smear, 100x).

Tumor resection was performed under balanced general anesthesia with orotracheal intubation, through a preauricular approach with submandibular extension of approximately five centimeters, dissection by planes and coagulation of small and medium caliber vessels through the use of ultrasonic vibration scissors until reaching the lesion, respecting the integrity of the parotid gland, as well as the marginal branch of the facial nerve, the tumor was removed, the hemostasis of the surgical bed was verified and it was sutured by planes. Figure 4. 


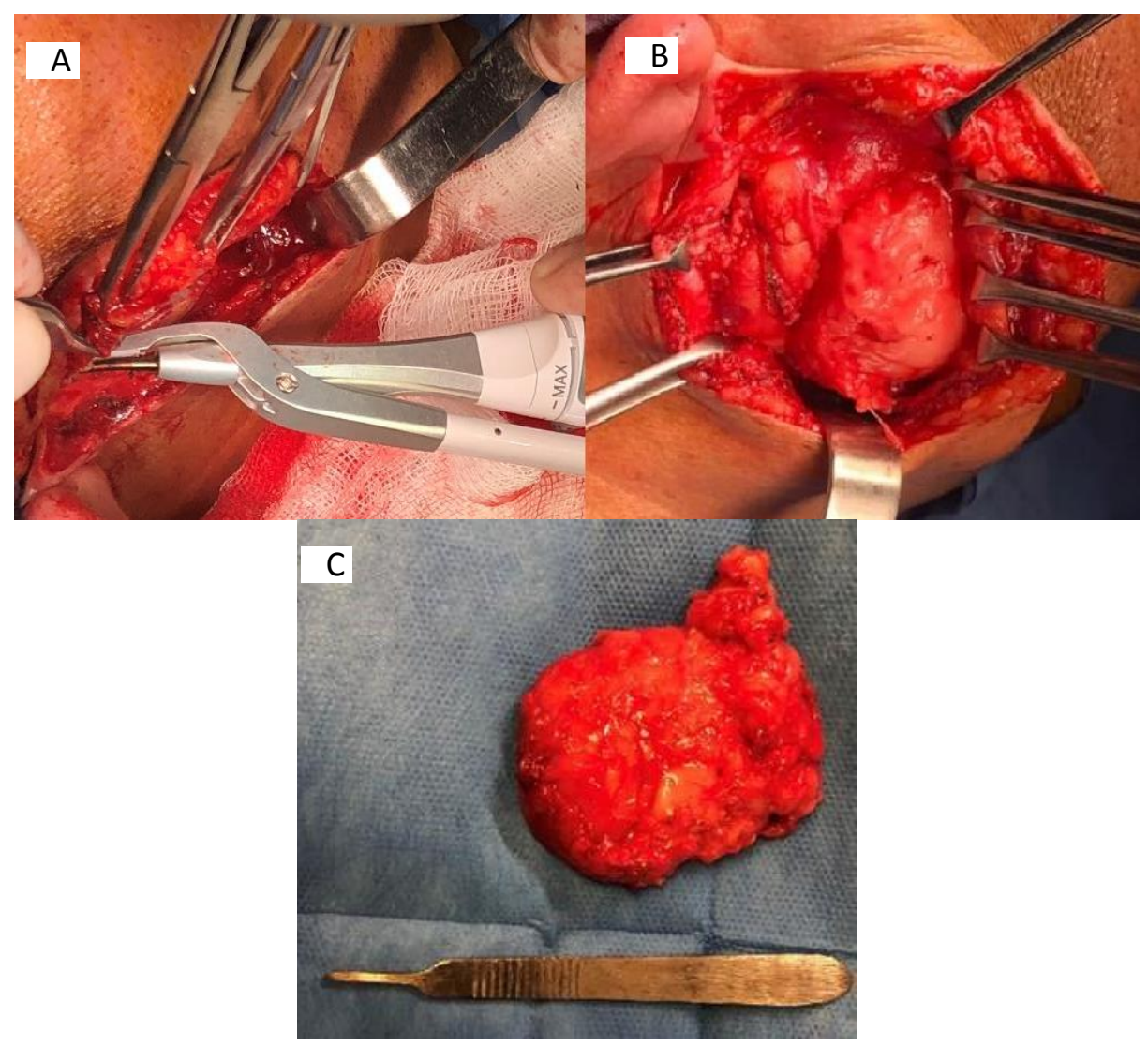

Figure 4: Surgical procedure. A) Dissection by planes and coagulation with ultrasonic vibration clamps, B) Tumor resection, C) Surgical specimen. In the histological sections, a lesion of mesenchymal line was seen, formed by broad lobes of mature adipose tissue, separated by delicate septum of wellvascularized lax fibrous tissue and well delimited by a thin layer of mature fibrous tissue, compatible with lipoma.

\section{Case report 2}

A 58-year-old female patient with a history of controlled type II diabetes, with a two-year increase in volume in the left parotid region of slow growth, firm consistency, subject to deep planes, with a diameter of four centimeters, not painful to palpation Requesting preoperative studies, salivary gland ultrasonography, reporting hypercoic area dependent on the left parotid gland, with presence of adjacent nodes and increased vascularity. Simple and contrasted computed tomography observing a hyper dense area of soft tissue with proximity to the carotid sheath and lymph nodes present, with a diagnostic impression of parotid gland tumor of the superficial lobe, lymphadenopathy and increased vascularity (Figure 5.)

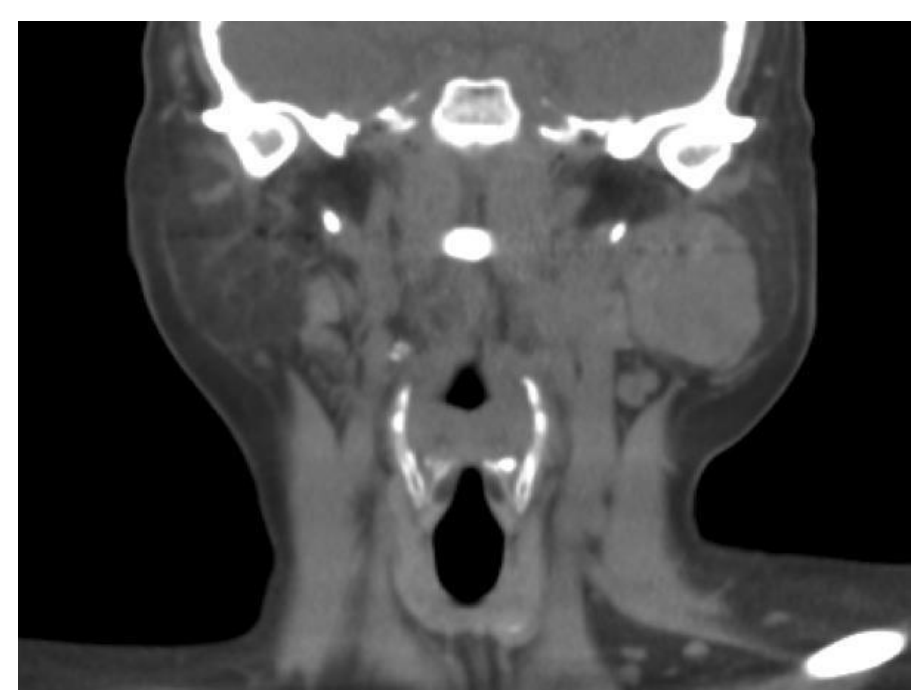

Figure. 5: Contrast tomography in coronal section showing hyperdense area in the left parotid region. 
Fine needle aspiration biopsy (BAAF) was performed, reporting polymorphonuclear cells with metaplastic changes in the epithelium, with a positive diagnostic interpretation of Whartin tumor.

Under balanced general anesthesia orotracheal intubation, prior asepsis and antisepsis, a three-centimeter submandibular approach was designed with pre and retroauricular extension, dissection of superficial cervical fascia and coagulation of small and medium-sized vessels with ultrasonic vibration scissors, appreciating tumor in Left parotid space approximately four centimeters in diameter, respecting the marginal branch of the nerve and facial vein, tumor resection is performed, sending tissue to a pathological study with a diagnosis of Whartin's tumor, observing a surgical bed without bleeding data, suturing by planes. (Figure 6).

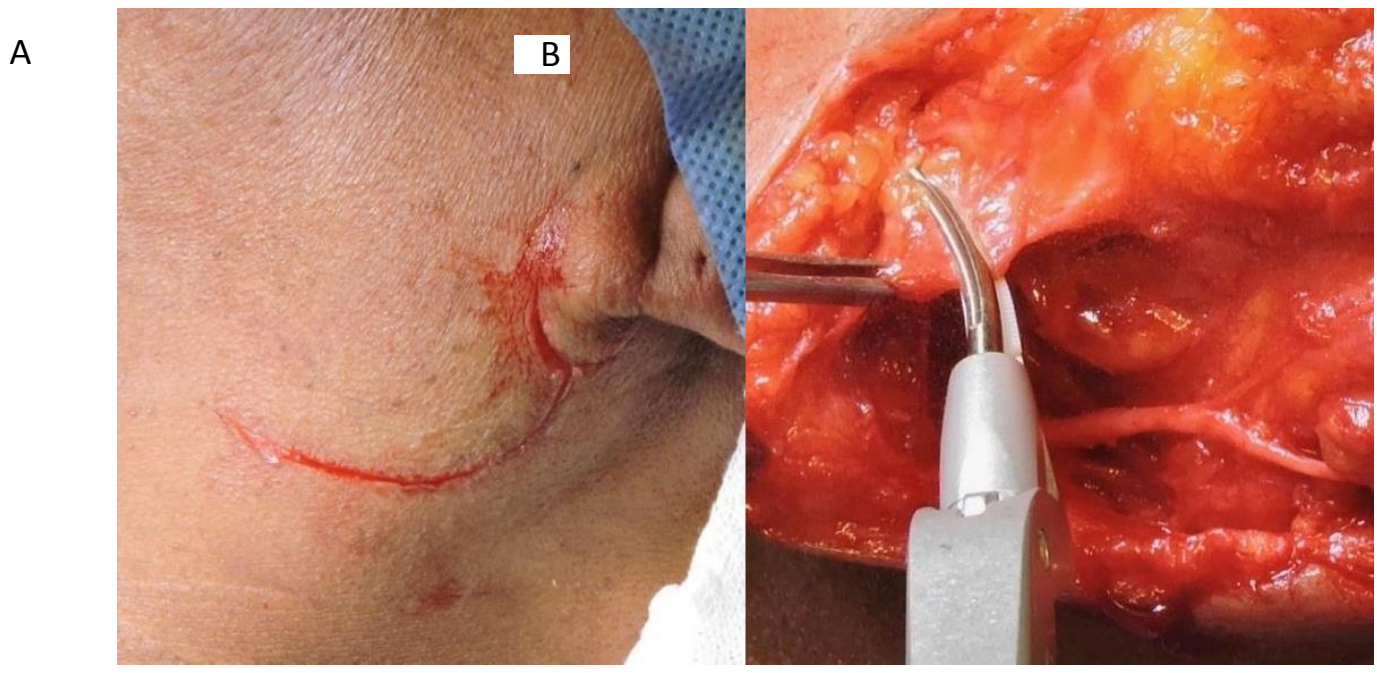

C

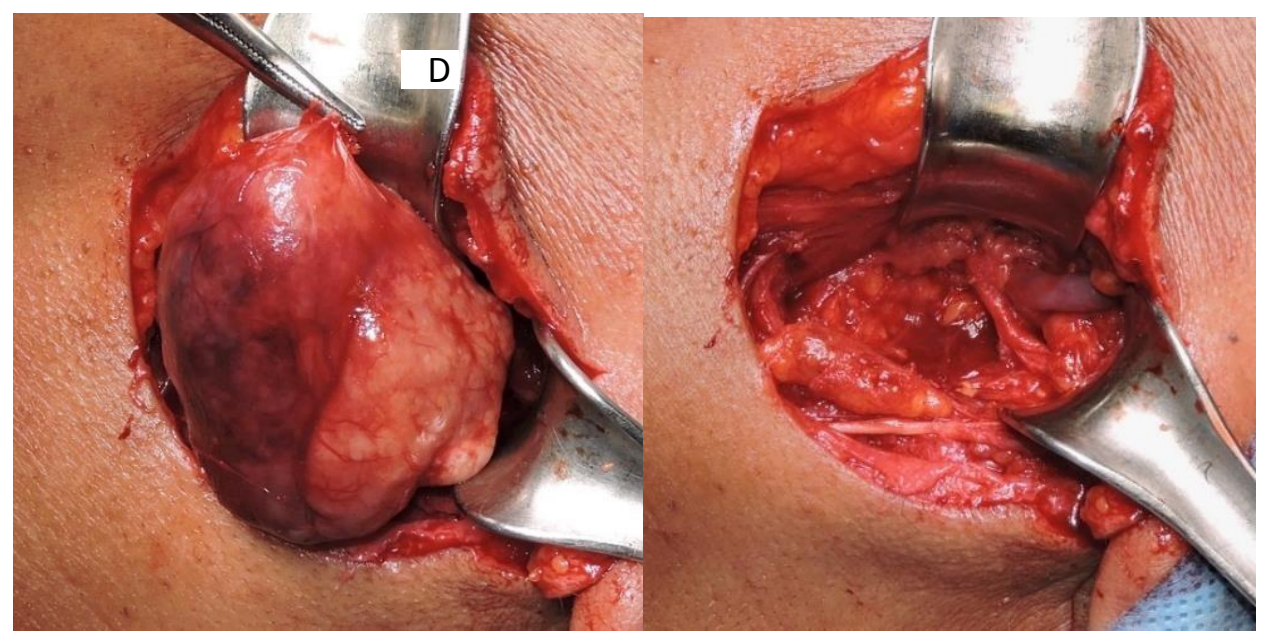

Figure 6: Surgical procedure A) Design of the incision less than 3 centimeters in length with pre and retro atrial extension, B) Dissection and coagulation with ultrasonic vibration scissors, C) Resection of parotid tumor, D) Surgical bed with marginal branch of the respected nerve and facial vein.

\section{Material and Methods}

Twelve patients of both sexes, between 39 and 76 years of age (mean of 57.5 years) admitted with a diagnosis of benign salivary gland tumor and cervical lymphadenopathy under study, for resection and / or excisional biopsy under general anesthesia were included for the study in the period from August 2018 to March 2019. A descriptive, longitudinal study was carried out. Inclusion criteria for patients of both sexes with controlled systemic disease, no neoplastic history and previous diagnosis by fine needle aspiration biopsy of benign tumor in major salivary glands and cervical lymphadenopathy of inflammatory origin. Exclusion criteria: patients with uncontrolled systemic diseases, with a history of malignant neoplastic tumors, with chemotherapy or prior radiotherapy. Elimination criteria, subjects who did not attend their appointments or who did not authorize the study. The procedure was performed under general anesthesia with orotracheal intubation and by extraoral approach, dissection with harmonic scissors of Harmonic brand, FocusMR (Johnson \& Johnson).7 the trans-surgical time was quantified in minutes from the incision until the suture of the surgical wound was finished. , the bleeding was quantified in milliliters. Table1. 


\begin{tabular}{|c|c|c|c|c|c|c|}
\hline Patient & $\begin{array}{c}\text { Sex } \\
\text { Blood loss }\end{array}$ & Age & Diagnosis & Procedure & In minutes & In milliliters \\
\hline 1 & $\mathrm{~F}$ & 50 & $\begin{array}{l}\text { submandibular } \\
\text { tumor }\end{array}$ & Submaxilectom & 50 & 35 \\
\hline $\begin{array}{c}2 \\
40\end{array}$ & M & 54 & lipoma & tumoral resection & 60 & \\
\hline 3 & M & 72 & Oncocytoma & tumoral resection & 45 & 60 \\
\hline $\begin{array}{c}4 \\
50\end{array}$ & $\mathrm{~F}$ & 42 & Whartin's tumor & submaxilectomy & 65 & \\
\hline $\begin{array}{c}5 \\
40\end{array}$ & M & 55 & $\begin{array}{l}\text { submandibular } \\
\text { tumor }\end{array}$ & submaxilectomy & 60 & \\
\hline $\begin{array}{c}6 \\
55\end{array}$ & $\mathrm{~F}$ & 72 & $\begin{array}{l}\text { submandibular } \\
\text { tumor }\end{array}$ & submaxilectomy & 50 & \\
\hline $\begin{array}{c}7 \\
45\end{array}$ & $\mathrm{~F}$ & 71 & $\begin{array}{l}\text { submandibular } \\
\text { sialoadenitis }\end{array}$ & submaxilectomy & 45 & \\
\hline $\begin{array}{c}8 \\
60\end{array}$ & M & 69 & Whartin's tumor & submaxilectomy & 40 & \\
\hline $\begin{array}{c}9 \\
30\end{array}$ & $\mathrm{~F}$ & 39 & $\begin{array}{l}\text { Submandibular } \\
\text { sialoadenitis } \\
\text { Cervical } \\
\text { lymphadenopathy }\end{array}$ & $\begin{array}{l}\text { submaxilectomy } \\
\text { lymph node } \\
\text { resection }\end{array}$ & 20 & \\
\hline $\begin{array}{l}10 \\
45\end{array}$ & $\mathrm{~F}$ & 47 & $\begin{array}{c}\text { Parotid tumor } \\
\text { Parotideal } \\
\text { lymphadenopathy }\end{array}$ & $\begin{array}{l}\text { parotidectomy } \\
\text { ganglion resection }\end{array}$ & 45 & \\
\hline $\begin{array}{l}11 \\
65\end{array}$ & $\mathrm{~F}$ & 76 & $\begin{array}{l}\text { Parotid tumor } \\
\text { Cervical } \\
\text { lymphadenopathy }\end{array}$ & $\begin{array}{l}\text { parotidectomy } \\
\text { ganglion resection }\end{array}$ & 75 & \\
\hline $\begin{array}{l}12 \\
50\end{array}$ & $\mathrm{~F}$ & 43 & $\begin{array}{c}\text { Parotid tumor } \\
\text { Cervical } \\
\text { lymphadenopathy }\end{array}$ & $\begin{array}{c}\text { parotidectomy } \\
\text { ganglion resection }\end{array}$ & 65 & \\
\hline
\end{tabular}

Table 1. Procedure time and blood loss using ultrasonic vibration.

\section{Results}

the results obtained were captured in an Excel spreadsheet and evaluated through the SPSS program to know measures of central tendency.

Of the twelve patients included in the study, 3 (25\%) were male and 9

(75\%) female, the most frequent diagnosis was benign submandibular gland tumor (33.3\%), followed by cervical lymphadenopathy (25\%), submandibular sialoadenitis $(25 \%)$, parotid lymphadenopathy $(8.3 \%)$, and lipoma $(8.3 \%)$, the most frequently performed surgery was submaxilectomy (50\%), followed by superficial parotidectomy (33.3\%) and lymph node resection ( $16.6 \%)$. Table 2 . 


\begin{tabular}{|c||c|c|}
\hline \multicolumn{1}{|c||}{} & Time & Blood loss \\
\hline $\mathrm{N}$ & 12 & 12 \\
\hline Mean & 44.1667 & 42.9167 \\
\hline $\begin{array}{c}\text { Standard } \\
\text { Error }\end{array}$ & 4.02800 & 3.39665 \\
\hline Median & 45.0000 & 42.5000 \\
\hline Mode & $35.00 \mathrm{a}$ & $30.00 \mathrm{a}$ \\
\hline $\begin{array}{c}\text { Standard } \\
\text { Deviation }\end{array}$ & 13.95339 & 11.76635 \\
\hline Variance & 194.697 & 138.447 \\
\hline Mínimum & 20.00 & 25.00 \\
\hline Maximum & 65.00 & 60.00 \\
\hline Total & 530.00 & 515.00 \\
\hline
\end{tabular}

Table 2. Measures of central time trend and intraoperative bleeding.

There is no significant correlation between bleeding presented by the 12 patients with the time of the surgical procedure. There was greater bleeding in patients undergoing parotidectomy, in relation to those of submaxilectomy. Graphic 1.

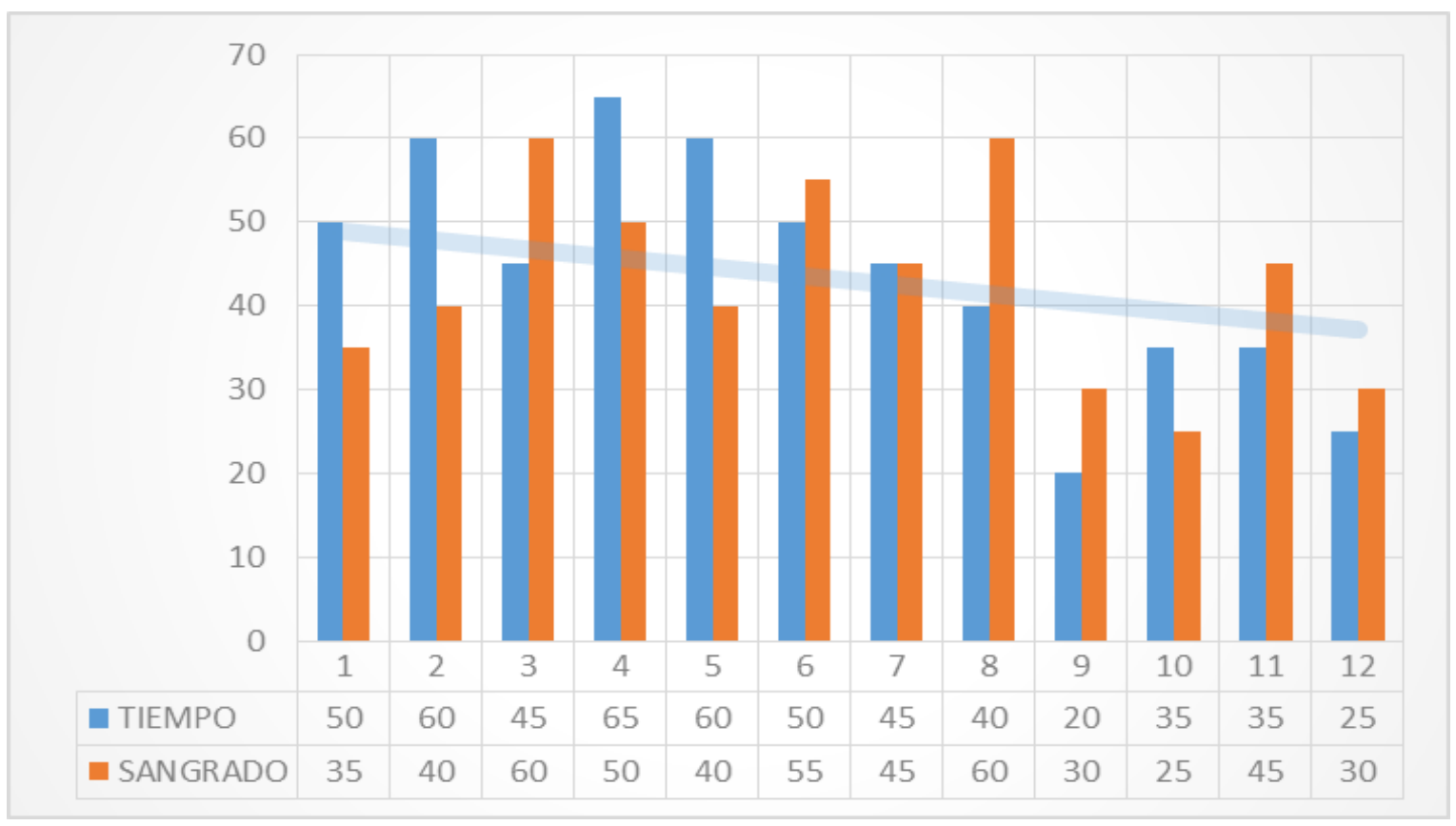

Graphic 1. Histogram of time and intraoperative bleeding.

The intraoperative time lasted from 20 to 65 minutes with an average 44.16 minutes. Graphic 2 . 


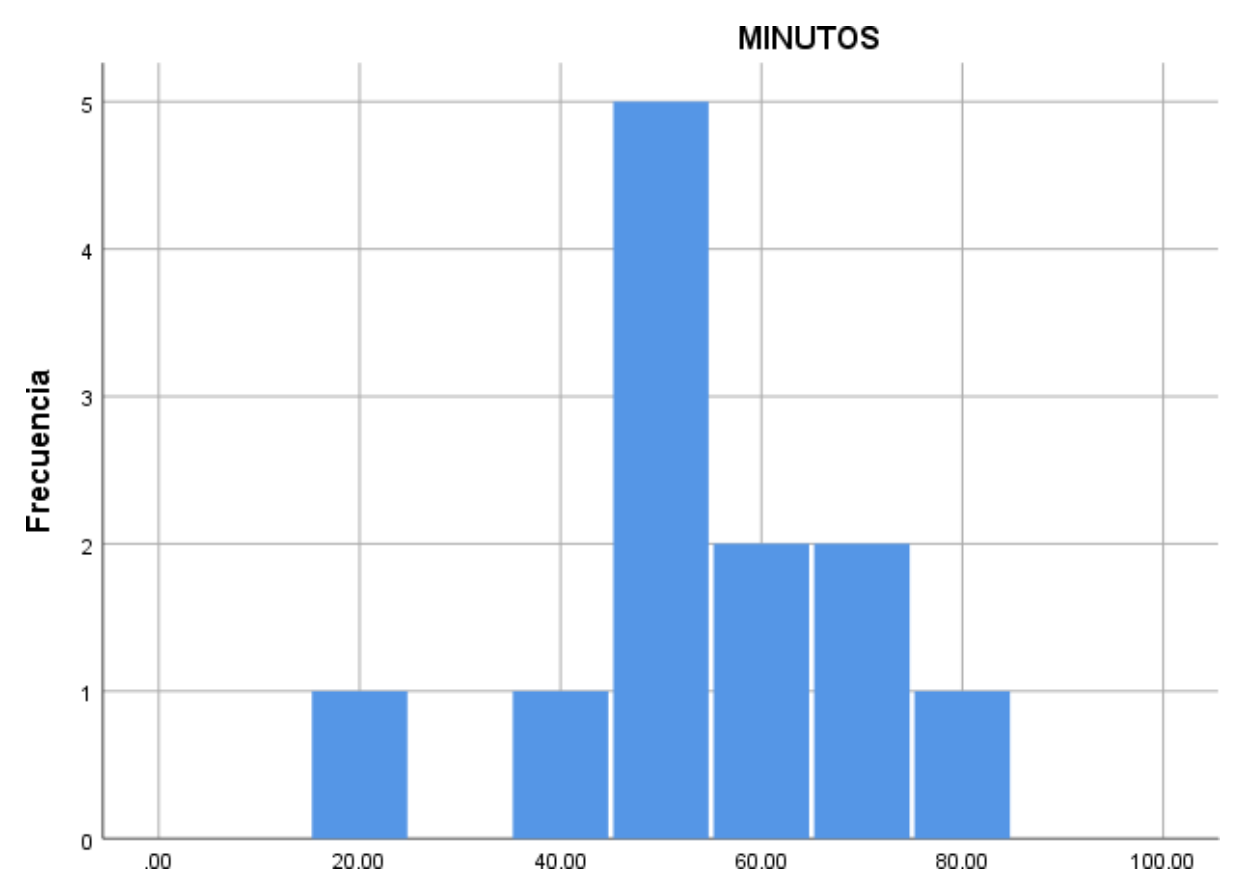

Graphic 2. Histogram of frequency in minutes of the 12 procedures performed.

Bleeding ranged from 25 to 60 milliliters with an average of 42.9 milliliters. Graphic 3.

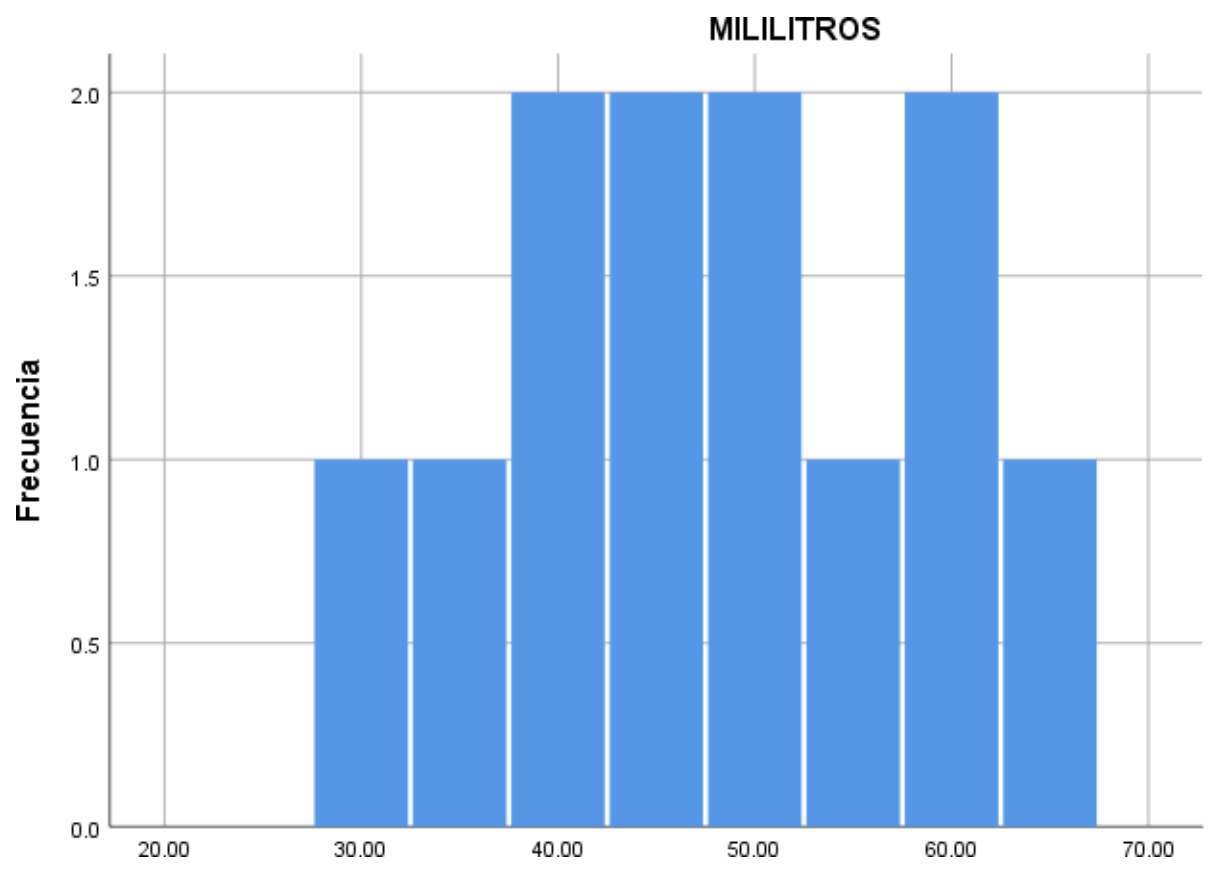

Graphic 3. Histogram of frequency in milliliters of the 12 procedures performed.

\section{Discussion}

Ultrasonic coagulation is a surgical tool, implemented in head and neck surgery since 1991. The ultrasonic vibration scissors, consist of a vibrating blade that oscillates at a frequency of $55.5 \mathrm{kHz}$ and a temperature that does not exceed $100^{\circ} \mathrm{C}[8,9]$.
Fan et al. demonstrated the use of ultrasonic vibration scissors for the resection of benign lesions at the base of the tongue through the transoral approach, reducing surgical duration and Tran's operative hemorrhage [10].

Koh et al mentioned less damage to nerve structures in neck dissections using ultrasonic vibration than with the use of electrosurgery [11]. 
The coagulation of the tissue originates through the denaturation of proteins, breaking the hydrogen bonds due to the high vibrational energy transferred to the tissue with the ultrasonic energy. Due to the absence of high temperatures, the tissue does not boil or carbonize, it simply bleaches and coagulates [12,14].

Currently, a decrease in operative time has been reported in the world literature, as well as a significant decrease in hemorrhagic complications in the Trans and postoperative period through the use of ultrasonic vibration instruments in head and neck surgery $[15,19]$.

\section{Conclusions}

the harmonic scalpel (HS) (Ethicon, Somerville, NJ), an instrument that uses ultrasonic vibrations to induce tissue cutting and immediate coagulation, was introduced in the early 1990s [7, 10].

A low power setting allows for greater hemostasis and a slower cut, while a high power setting offers less hemostasis but a faster cutting capacity. Ultrasonic vibration has been shown to reduce operative time and intraoperative blood loss in a range of procedures including from thyroidectomy, parotidectomy, glosectomy and neck dissection $[15,18]$. According to the data obtained, it can be concluded that the time and trans operative bleeding decrease considerably with the use of ultrasonic vibration, coinciding with that reported by the articles reviewed $[19,20]$.

\section{References}

1. Auclair PL. Ellis GL. Gnepp DR. (1991). Salivary Gland Neoplasms: general considerations. Surgical pathology of the Salivary Glands. Saunders, Philadelphia, 135-148.

2. Deganello A, Meccariello G, Busoni M, Parrinello G, Bertolai R, Gallo O. (2014). Dissection with harmonic scalpel versus cold instruments in parotid surgery. B-ENT, 10(3):175-178.

3. Balagué C. Hemostasia y Tecnología. Energía. (2009). Desarrollo de nuevas tecnologías. Cir. Esp. 85 (supl 1): 15-22.

4. Tirelli, G., Piero, G.C., \& Perrino, F. (2014). Ultracision Harmonic Scalpel in oral and oropharyngeal cancer resection. Journal of cranio-maxillo-facial surgery: official publication of the European Association for Cranio-Maxillo-Facial Surgery, 42 5, 544-547.

5. Mijares Briñez, Alirio, Suárez, Carmen María, PÉREZ, Carlos Alberto, Pacheco Soler, Carlos, \& Agudo, Esteban. (2006). Uso del bisturí armónico en la cirugía tiroidea. Revista Venezolana de Oncología, 18(4), 215-220

6. Montes Y, Zazueta M. (2015). Pérdida sanguínea por el peso de los textiles y su correlación con la hemoglobina posquirúrgica. Gac Med Mex., 152, 674-678.

7. Intelligent ultrasonic Energy instructive, Ethicon Johnson \& Johnson, medical instructions.

To Submit Your Article Click Here: Submit Manuscript 8.

DOI: $10.31579 / 2690-1897 / 025$
This work is licensed under Creative Commons Attribution 4.0 License
Thomas C, (2005). Alternative Surgical Dissection Techniques. Orl clinics of North America. 38(2): 397-411.

9. Fan S, Zhang D, Chen W. (2017). Endoscopy-Assisted Resection of Benign Lesions on the Base of the Tongue via the Transoral Approach Using a Harmonic Scalpel. Journal of Oral and Maxillofacial Surgery, 75 (10), 2242-2247.

10. Koh Y, Park J, Lee S, Choi E. (2008). The harmonic scalpel technique without supplementary ligation in total thyroidectomy with central neck dissection: a prospective randomized study. Ann Surg, 247(6):945-949.

11. Koh Y, Choi E. (2014). Robotic approaches to the neck. Otolaryngologic Clinics of North America, 3, 433-454.

12. Ferri E, Armato E, Spinato G, Lunghi M, Tirelli G, Spinato R. (2013). Harmonic scalpel versus conventional haemostasis in neck dissection: a prospective randomized study. Int J Surg Oncol, 339-345.

13. Cheng, H., Clymer, J., Sadeghirad, B., Ferko, N., Cameron, C. and Amaral, J. (2018). Performance of Harmonic devices in surgical oncology: an umbrella review of the evidence. World Journal of Surgical Oncology, 16(1).

14. Polacco, M.A., Pintea, A.M., Gosselin, B.J., \& Paydarfar, J.A. (2017). Parotidectomy using the Harmonic scalpel: ten years of experience at a rural academic health center. Head \& face medicine.

15. Koch C, Friedrich T, Metternich F, Tannapfel A, Reimann H, Eichfeld U. (2003). Determination of temperature elevation in tissue during the application of the harmonic scalpel. Ultrasound Med Biol, 29(2):301-309.

16. El-Monem MHA, Gaafar AH, Magdy EA. (2006). Lipomas of the head and neck: presentation variability and diagnostic workup. J Laryngol Otol, 120:47-55

17. Pons Y, Gauthier J, Clement P, Conessa C. (2009). Ultrasonic partial glossectomy. Head Neck Oncol, 6(1):21.

18. Dean A, Alamillos F, Centella I, Garcia-Alvarez S. (2014). Neck dissection with the Harmonic scalpel in patients with squamous cell carcinoma of the oral cavity. J Craniomaxillofac Surg, 42(1):84-87.

19. Hong, H. J., Koh, Y. W., Shin, Y. S., Lee, S.-Y., \& Choi, E. C. (2010). Sutureless Neck Dissection Using the Harmonic Scalpel. Otolaryngology-Head and Neck Surgery, 143(2_suppl), P204-P204.

20. Evaluation of the ultracision ultrasonic dissector in head and neck surgery Leonard D.S., Timon C. (2008) Operative Techniques in Otolaryngology - Head and Neck Surgery, 19 (1) , pp. 59-66.

$$
\begin{aligned}
& \text { Ready to submit your research? Choose Auctores and benefit from: } \\
& \text { fast, convenient online submission } \\
& \text { rigorous peer review by experienced research in your field } \\
& \text { rapid publication on acceptance } \\
& \text { authors retain copyrights } \\
& \text { unique DOI for all articles } \\
& \text { immediate, unrestricted online access }
\end{aligned}
$$

At Auctores, research is always in progress.

Learn more www.auctoresonline.org/journals/clinical-medical-reviewsand-reports 